\title{
Rancangan Sistem Informasi Keuangan Himpunan Mahasiswa Teknik Industri
}

\author{
Mochammad Rifky Fadillah 1201174310 \\ Telkom University \\ Email:mochrifky@telkomuniversity.ac.id
}

\begin{abstract}
.Information systems are starting to become an important requirement in our daily lives. This is proven because its function is very useful in doing work. In this case, the use of information systems that can facilitate the activities of organizations such as the Student Association in order to maximize organizational goals. The information system design was developed using software Microsoft Access because of its easy use. In addition, the design is also carried out using diagrams that are made from the work of the information system to be developed.
\end{abstract}

Keywords: Information System, Design, Diagrams.

Paper ini akan dipublikasikan di osf.io [a] menggunakan format standard perancangan sistem informasi [b]

\section{Introduction}

1.1. Business case

Dalam sebuah organisasi memiliki bagian, divisi, atau departemen yang memiliki tugas masing-masing untuk dapat mencapai tujuan suatu organisasi tersebut. Selain itu, ada beberapa hal lain yang penting dalam menjalankan sebuah organisasi, yaitu sumber dana atau keuangan. Tanpa uang atau dana, sebuah organisasi tidak akan berjalan dengan maksimal. Oleh karena itu, sumber manusia dan sumber dana merupakan faktor penting dalam keberlangsungan sebuah organisasi. Akan tetapi, dalam hal keuangan sering ditemukan masalah kurangnya transparasi kepada setiap anggota, sehingga dapat menimbulkan masalah internal di organisasi. Hal tersebut mendorong rancangan sistem informasi keuangan organisasi, khususnya di HMTI ini dibuat. Tujuan dari rancangan sistem informasi ini menggunakan SMART Rule, yaitu sebagai berikut.

1. Specific: mempermudah pencatatan serta transparasi keuangan organisasi HMTI.

2. Measurable: memaksimalkan pengeluaran dan pemasukan keuangan hingga $90 \%$.

3. Agreed Upon: menurunkan kesalahpahaman mengenai pengeluaran dan pemasukan keuangan.

4. Realistic: dapat terus digunakan selama periode kepengurusan masih berjalan.

5. Time-bound: projek dapat selesai sesuai batas waktu yang telah ditentukan.

Sistem adalah suatu jaringan kerja dari prosedur-prosedur yang saling berhubungan, berkumpul bersama untuk melakukan suatu kegiatan atau untuk menyelesaikan suatu sasaran tertentu, sementara informasi adalah data yang diolah menjadi bentuk yang lebih berguna bagi yang menerimanya [1]. Sehingga, sistem informasi adalah suatu kombinasi teratur apapun dari orang, perangkat keras, perangkat lunak, jaringan komunikasi, dan basis data yang mengumpulkan, mengubah, dan menyebarkan informasi di dalam suatu organisasi [2]. Pada sistem informasi memiliki fungsi dasar, yaitu input, processing, dan juga output. Pada rancangan sistem informasi yang akan dibahas, input memiliki peran dengan memasukkan data keuangan berupa pengeluaran dan pendapatan atapun memasukkan data username yang akan diprocess pada fungsi processing. Kemudian pada output merupakan hasil pada saat input telah diproses, yaitu hasil laporan keuangan yang telah diinput sebelumnya. 


\subsection{System Requirement}

Dalam sistem informasi yang akan dirancang meliputi beberapa fungsi, yaitu mengumpulkan penginputan data, menyimpan data, memproses sebuah data yang dinputkan, dan menghasilkan output dari informasi tersebut. Adapun fitur yang diberikan pada sistem informasi ini, antara lain sebagai berikut:

1. Update: memperbarui data yang kemudian akan disimpan pada database.

2. Create: membuat akun untuk mengakses sistem informasi ini.

3. Delete: menghapus data yang tidak valid ataupun data yang sudah tidak digunakan.

4. Report: menampilkan hasil data yang diakses.

Pada sistem yang sedang dikembangkan tentu memiliki indikator kriteria yang menjadi dasar bahwa sistem yang sedang dilakukan sudah dapat berfungsi sebagaimana mestinya dan sesuai dengan fitur yang sudah diberikan. Indikator kriterianya, yaitu fitur yang telah dibuat sebelumnya. Adapun level user pada rancangan sistem informasi yang dikembangkan ini, yaitu pengguna yang terdaftar pada sistem dan dapat mengakses langsung ke sistem, selain itu juga memiliki tingkatan untuk membatasi pengaksesan dari sistem informasi. Level user yang digunakan pada rancangan sistem informasi ini terdiri dari, yaitu Admin yang terdiri dari bendahara dan Staff yang terdiri dari seluruh anggota organisasi selain bendahara.

\section{Penjelasan SIngkat Terkait Metode}

Perancangan sistem informasi ini menggunakan Computer-Based Information System (CBIS), yaitu satu set perangkat keras, perangkat lunak, basis data, telekomunikasi, orang, dan prosedur yang dikonfigurasi untuk mengumpulkan, memanipulasi, menyimpan, dan mengolah data dari informasi [3]. Metode yang digunakan untuk mengembangkan sebuah sistem informasi adalah System Development Life Cycle (SLDC), yaitu meliputi perencanaan, analisis, perancangan, implementasi, serta pemeliharaan [4]. Pada Figure.1 dapat dilihat tahap pertama terdapat Planning, di mana total kebutuhan sistem informasi organisasi diidentifikasi, dianalisis, diprioritaskan, dan diatur. Kemudian fase kedua adalah Analysis, yaitu persyaratan maupun kebutuhan sistem dipelajari dan disusun. Selanjutnya Design, di mana solusi yang disaran-kan diubah menjadi spesifikasi sistem logis dan kemudian fisik. Fase keempat adalah Implementation, yaitu sistem informasi dikodekan, diuji, diinstalm dan didukung dalam organisasi. Fase terakhir adalah Maintenance di mana sistem informasi secara sistematis diperbaiki dan ditingkatkan. Akan tetapi dalam perancangan sistem informasi organisasi ini hanya akan sampai pada implementasi saja karena keterbatasan waktu yang dimiliki.

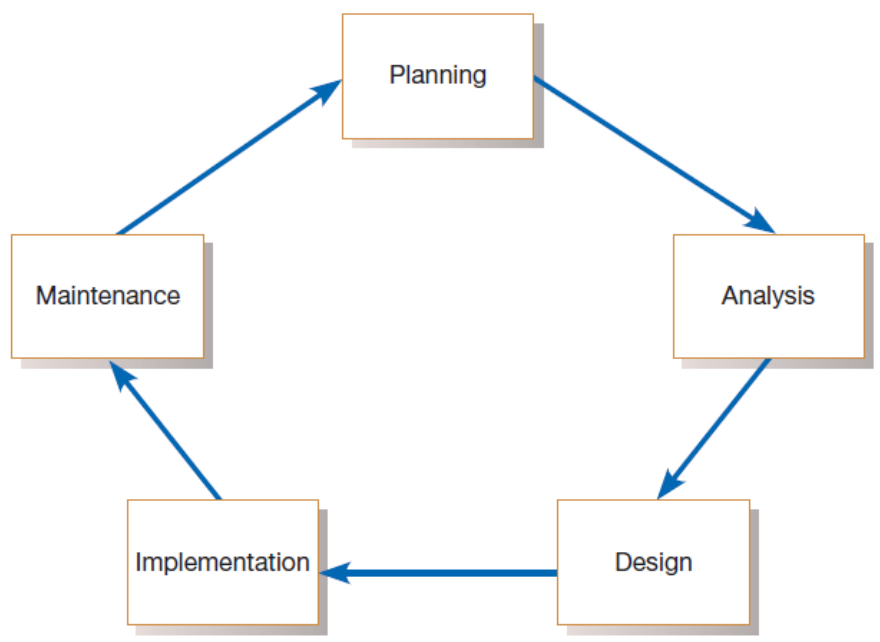

Figure 1. System Development Life Cycle 


\section{Proses Perhitungan}

\subsection{System Design}

Pada langkah perancangan sistem informasi yang telah dijelaskan sebelumnya, terdapat fase atau tahap perancangan sistem. Perancangan sistem pada pengembangan sistem informasi organisasi HMTI, yaitu meliputi hasil analisis yang telah dilakukan. Analisis yaitu berupa penentuan kebutuhan sistem. Metode yang digunakan dalam menentukan kebutuhan sistem adalah dengan metode Agile dengan pendekatan Continual User Involvement, di mana melibatkan pengguna secara terus-menerus di seluruh proses analisis perancangan. Selanjutnya yang dilakukan adalah menata kebutuhan sistem tersebut.

Tabel 1. Tabel Basis Data Keuangan

\begin{tabular}{ccc}
\hline No. & Field Name & Data Type \\
\hline 1 & Invoice & Short Text(50) PK \\
2 & Cash_In & Currency \\
3 & Cash_Out & Currency \\
4 & Tanggal & Date/Time \\
5 & Keterangan & Long Text \\
\hline
\end{tabular}

Tabel 2. Tabel Basis Data User

\begin{tabular}{ccc}
\hline No. & Field Name & Data Type \\
\hline 1 & ID_User & Short Text(50) \\
2 & Password & Short Text(50) \\
3 & Nama & Short Text(50) \\
4 & NIM & Number \\
5 & Jabatan & Short Text(50) \\
\hline
\end{tabular}

3.2. Data Flow Diagram (DFD)

Salah satu tahap penataan kebutuhan sistem adalah dengan merancang data flow diagram, yaitu gambar pergerakan data antara entitas eksternal, proses, dan penyimpanan data dalam suatu sistem. Berikut dapat dilihat pada Figure 2 .

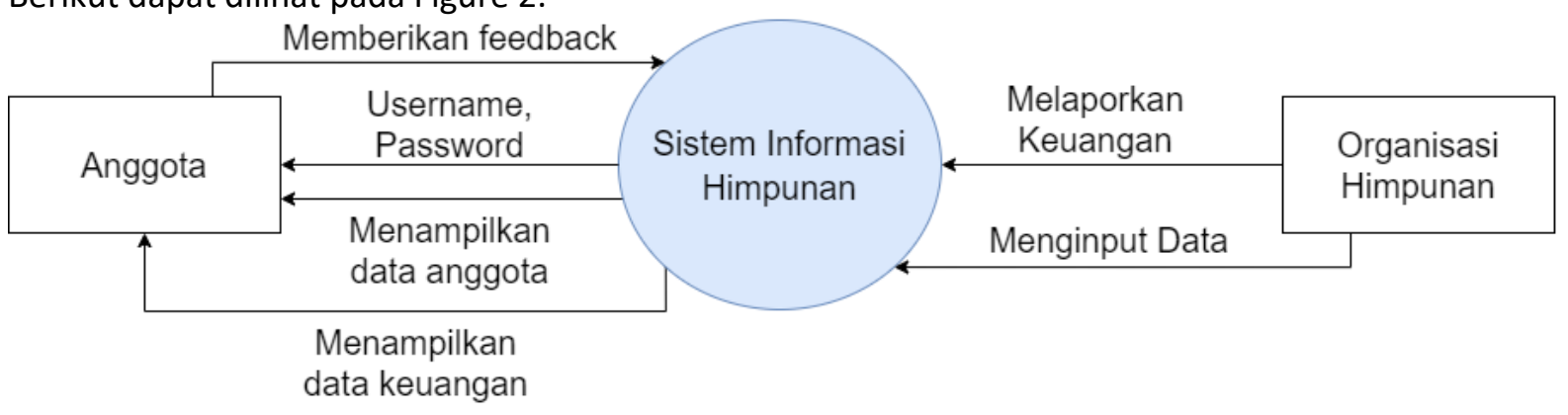

Figure 2. Gambar Data Flow Diagram Level 0

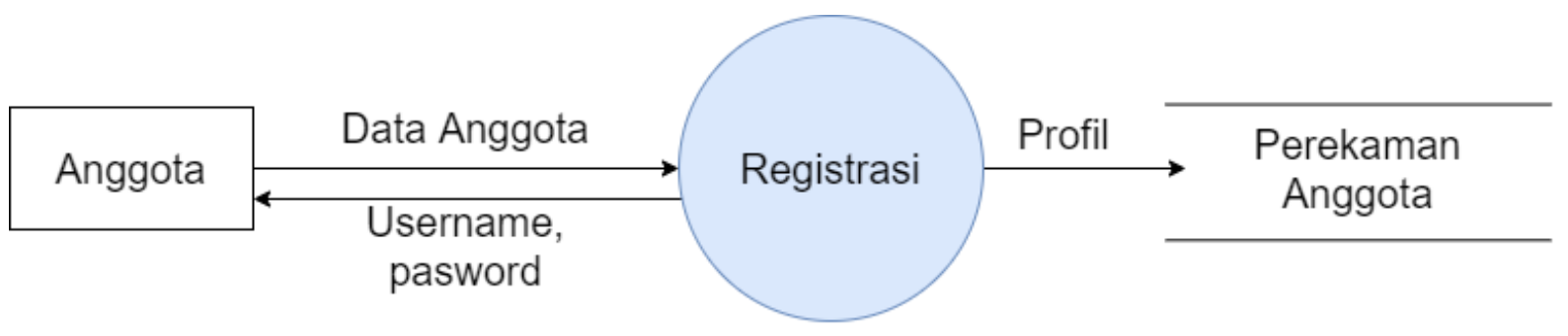


Figure 3. Gambar Data Flow Diagram Level 1

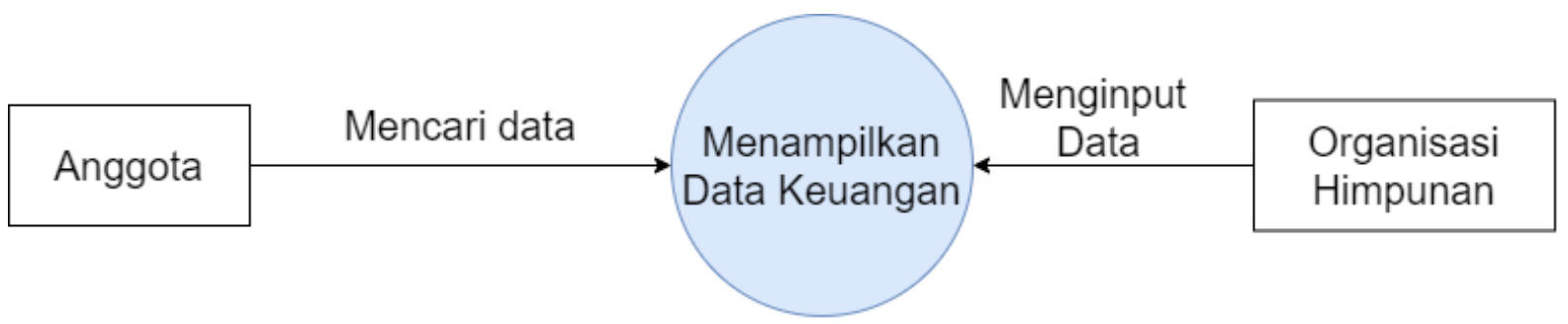

Figure 4. Gambar Data Flow Diagram Level 2

\subsection{Entity Relationship Diagram (ERD)}

Entity-Relationship Data Model adalah representasi yang terperinci dan logis dari entitas, asosiasi, dan elemen data untuk organisasi atau area bisnis. Secara umum, E-R model digambarkan dengan E-R Diagram yang merepresentasikan E-R model dalam grafis. Berikut ERD dapat dilihat pada Figure 3.

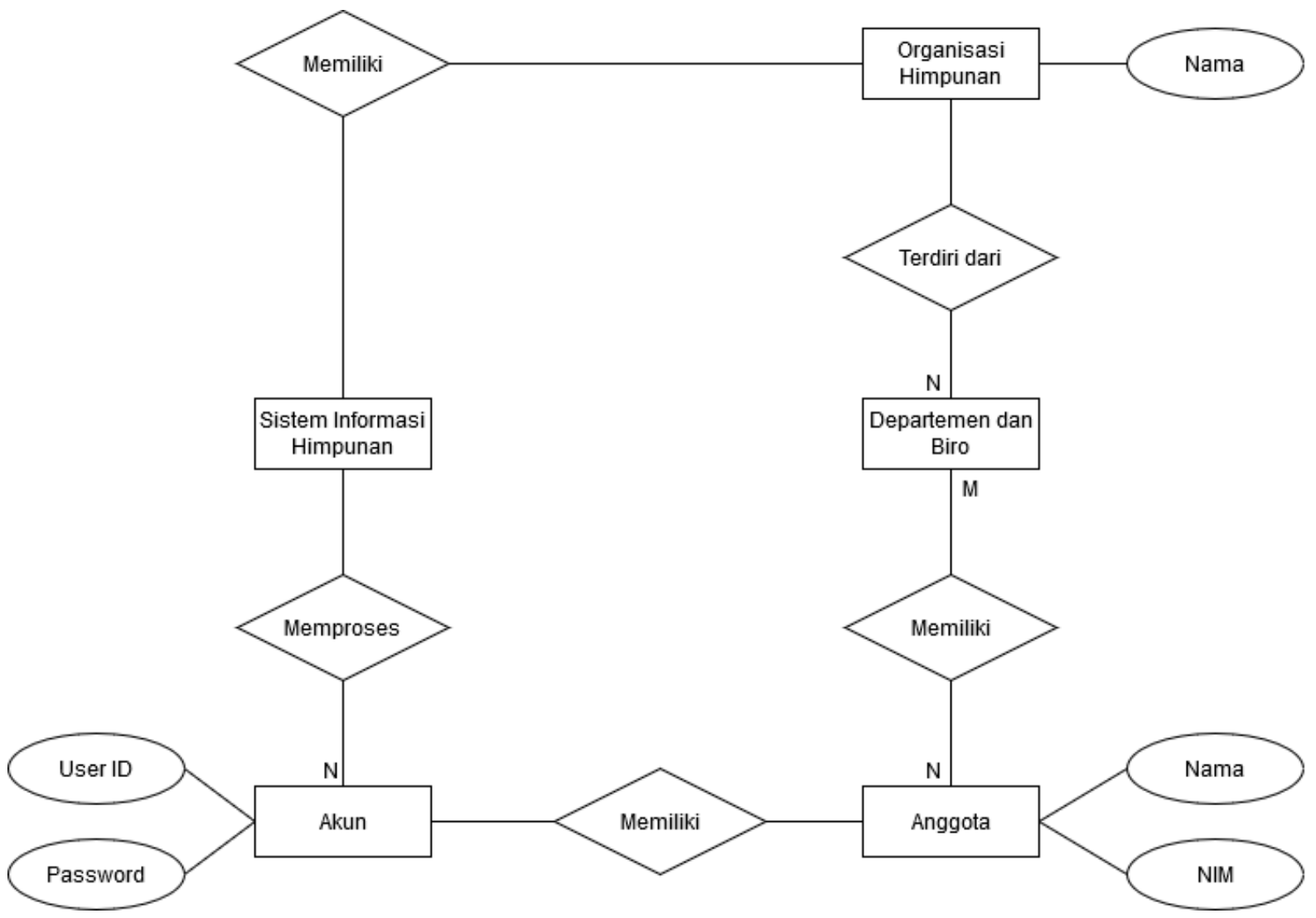

Figure 5. Gambar ERD

\subsection{Database Design}

Setelah melakukan perancangan diagram seperti di atas, selanjutnya melakukan perancangan pada pembuatan database untuk sistem informasi yang akan dikembangkan di mana perancangan database seperti pada Tabel 1 . dan Tabel 2.

\subsection{Use Case Diagram}


Use Case Diagram merupakan penggambaran perilaku atau fungsi sistem dalam berbagai kondisi saat sistem merespons permintaan dari pengguna [4]. Akan tetapi, dalam use case diagram di bawah ini hanya penggambaran fungsi sistem pada perilaku admin.

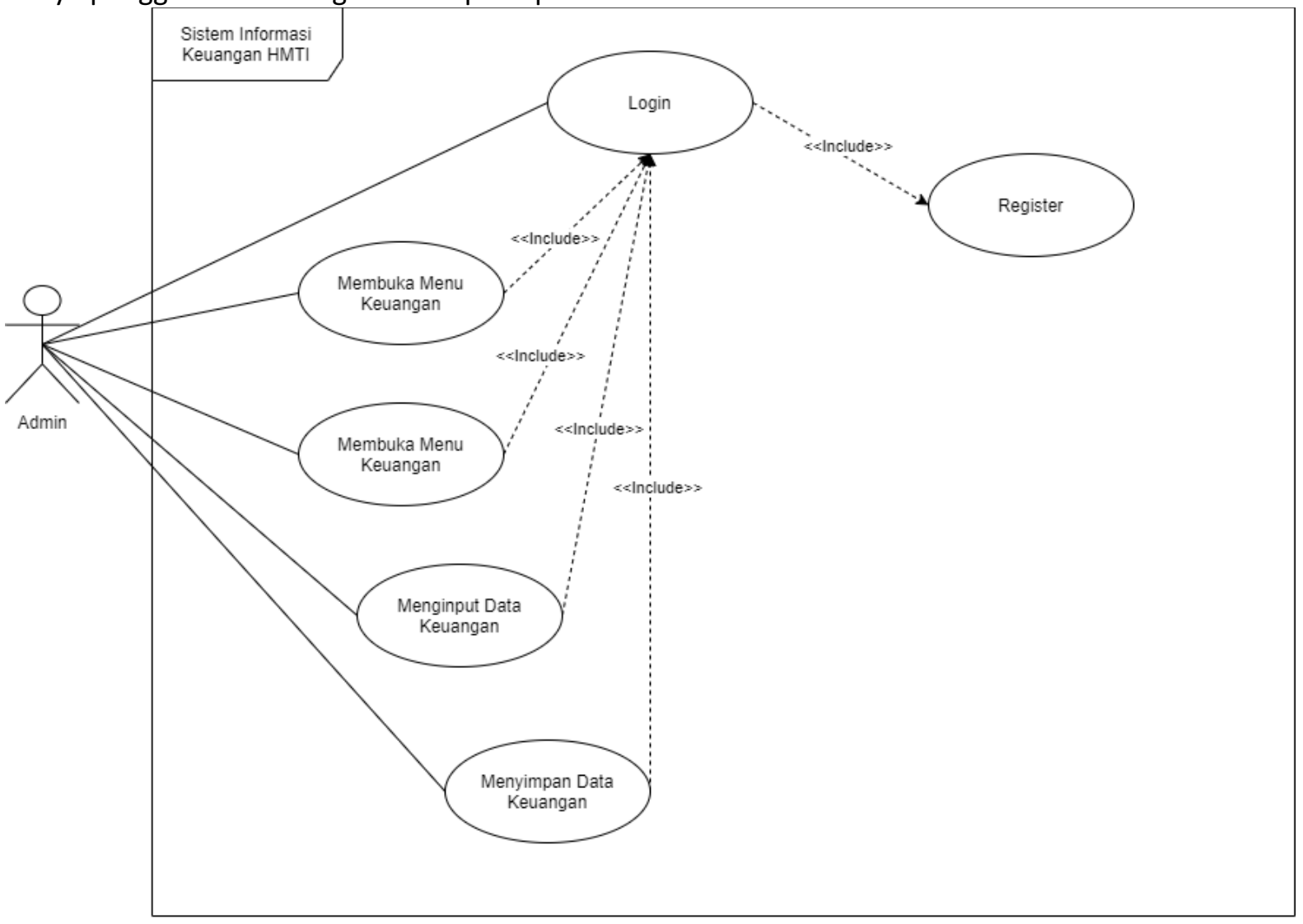

Figure 6. Gambar Use Case Diagram

\subsection{Activity Diagram}

Activity Diagram menunjukkan logika kondisional untuk urutan aktivitas sistem yang diperlukan untuk menyelesaikan proses bisnis [4]. Pada activity diagram di bawah ini menunjukkan aktivitas yang dilakukan oleh seorang admin dalam menggunakan sistem informasi. 


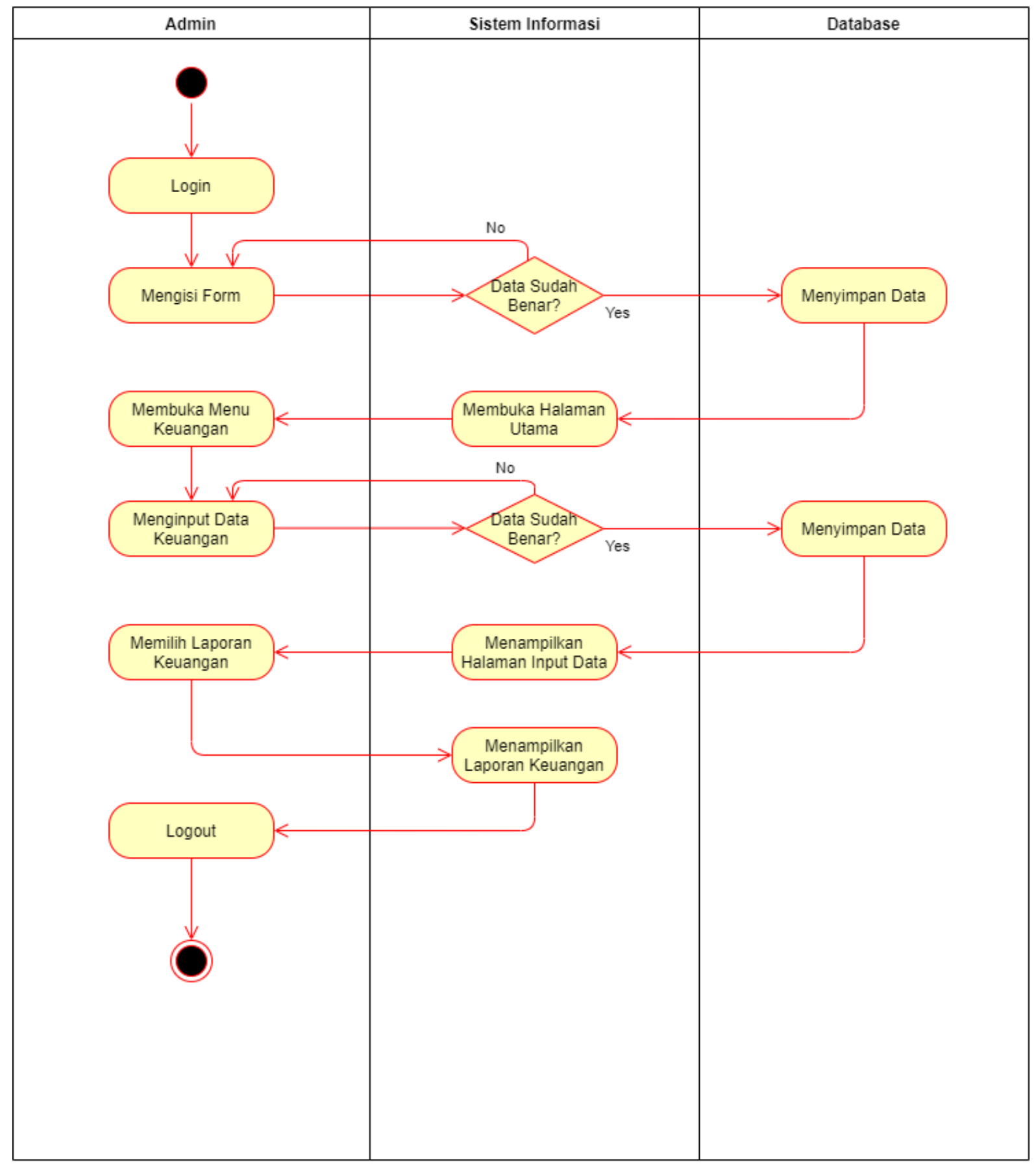

Figure 6 Gambar Activity Diagram

\subsection{Sequence Diagram}

Sequence Diagram menggambarkan interaksi di antara objek selama periode waktu tertentu [4]. Pada sequence diagram di bawah ini menunjukkan interaksi pada user admin dengan sistem informasi. 


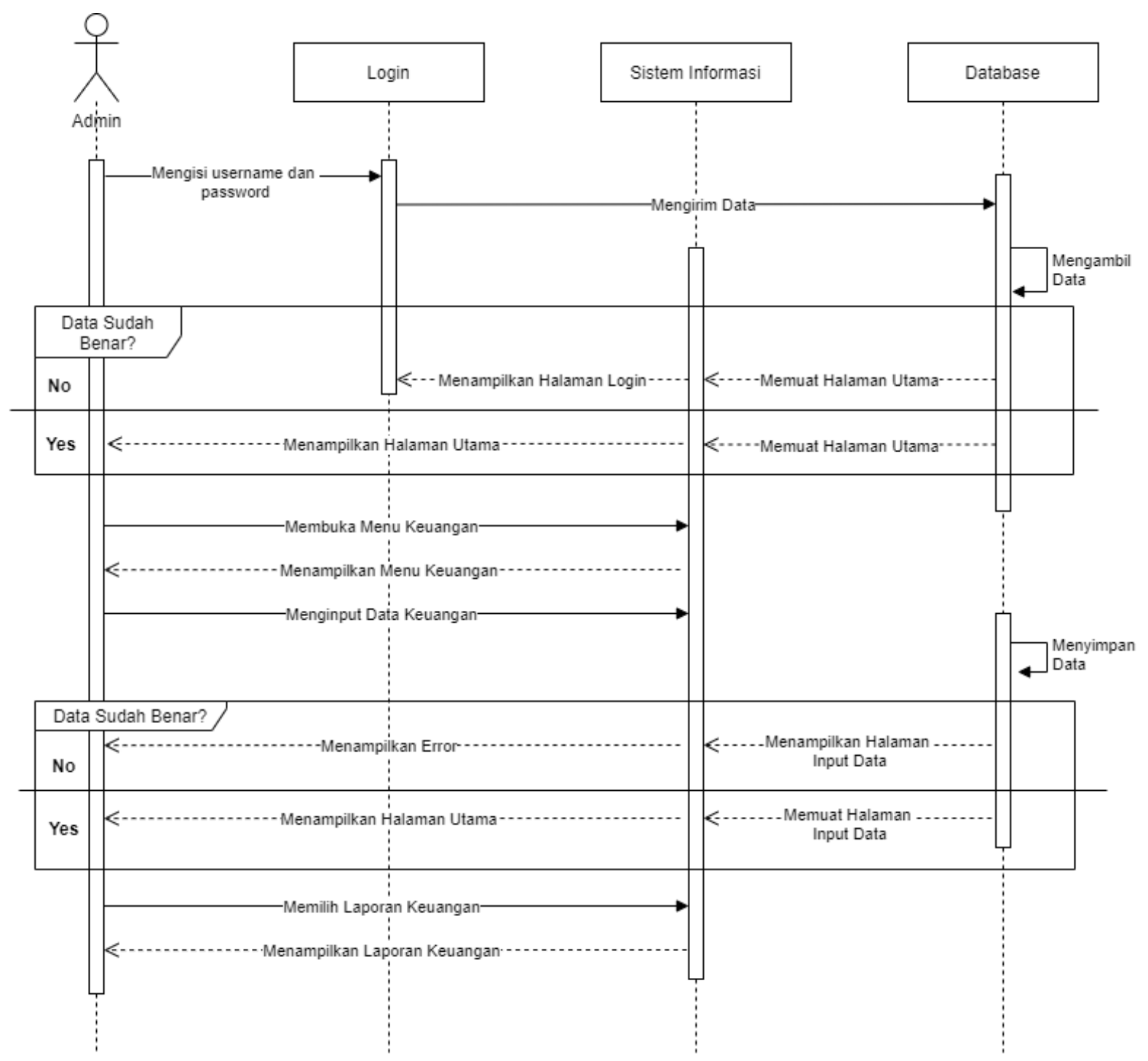

Figure 7. Gambar Sequence Diagram

\subsection{Interface Design}

Rancangan antarmuka berfokus pada bagaimana informasi diberikan dan ditangkap dari pengguna. Pada perancangan sistem informasi ini menggunakan aplikasi Microsoft Access di mana merupakan aplikasi yang mudah untuk mengembangkan rancangan sistem informasi. Berikut ini merupakan rancangan antarmuka dari sistem yang dapat dilihat pada Figure 8-14. 


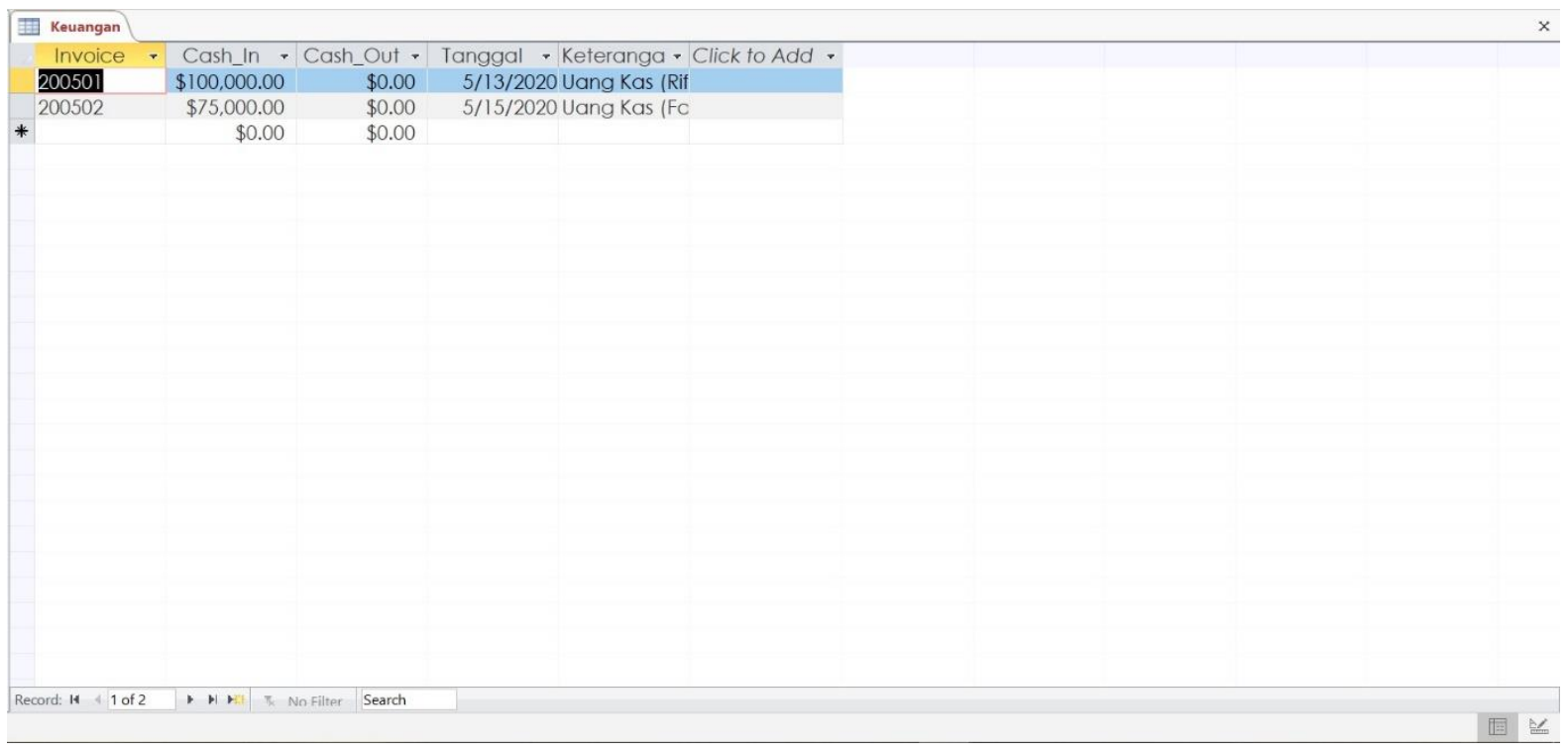

Figure 8. Gambar Interface Design Database Keuangan

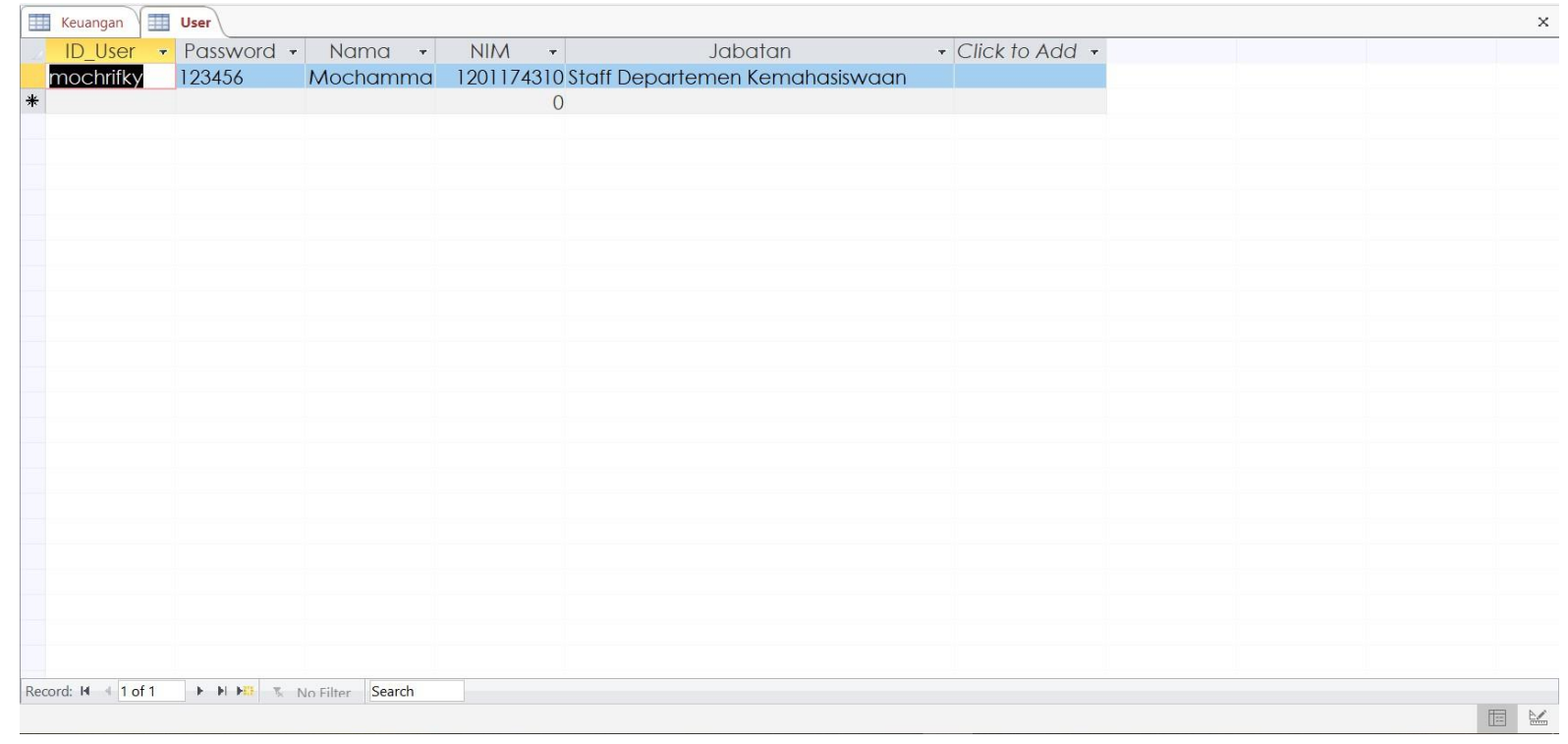

Figure 9. Gambar Interface Design Database User 


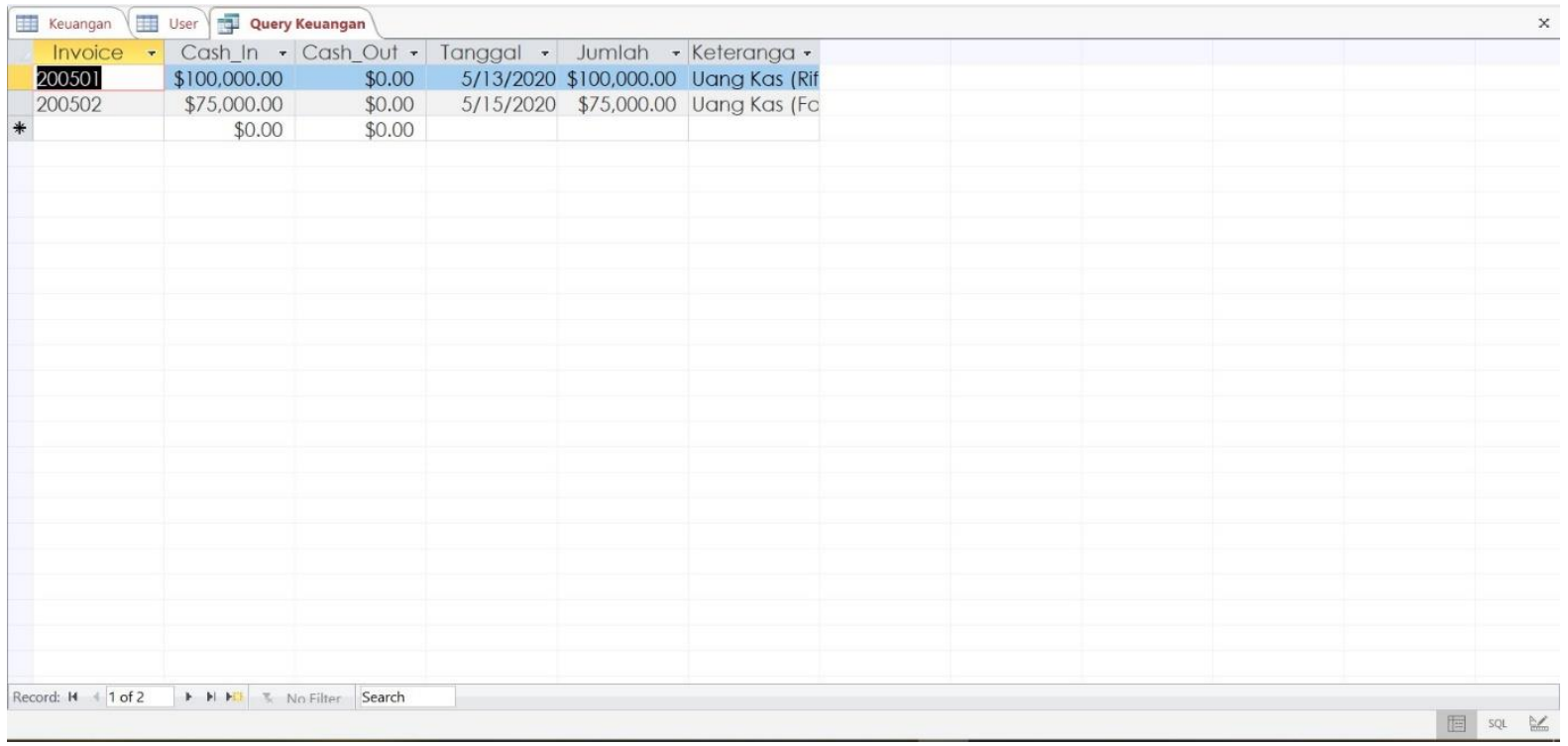

Figure 10. Gambar Interface Design Query Keuangan

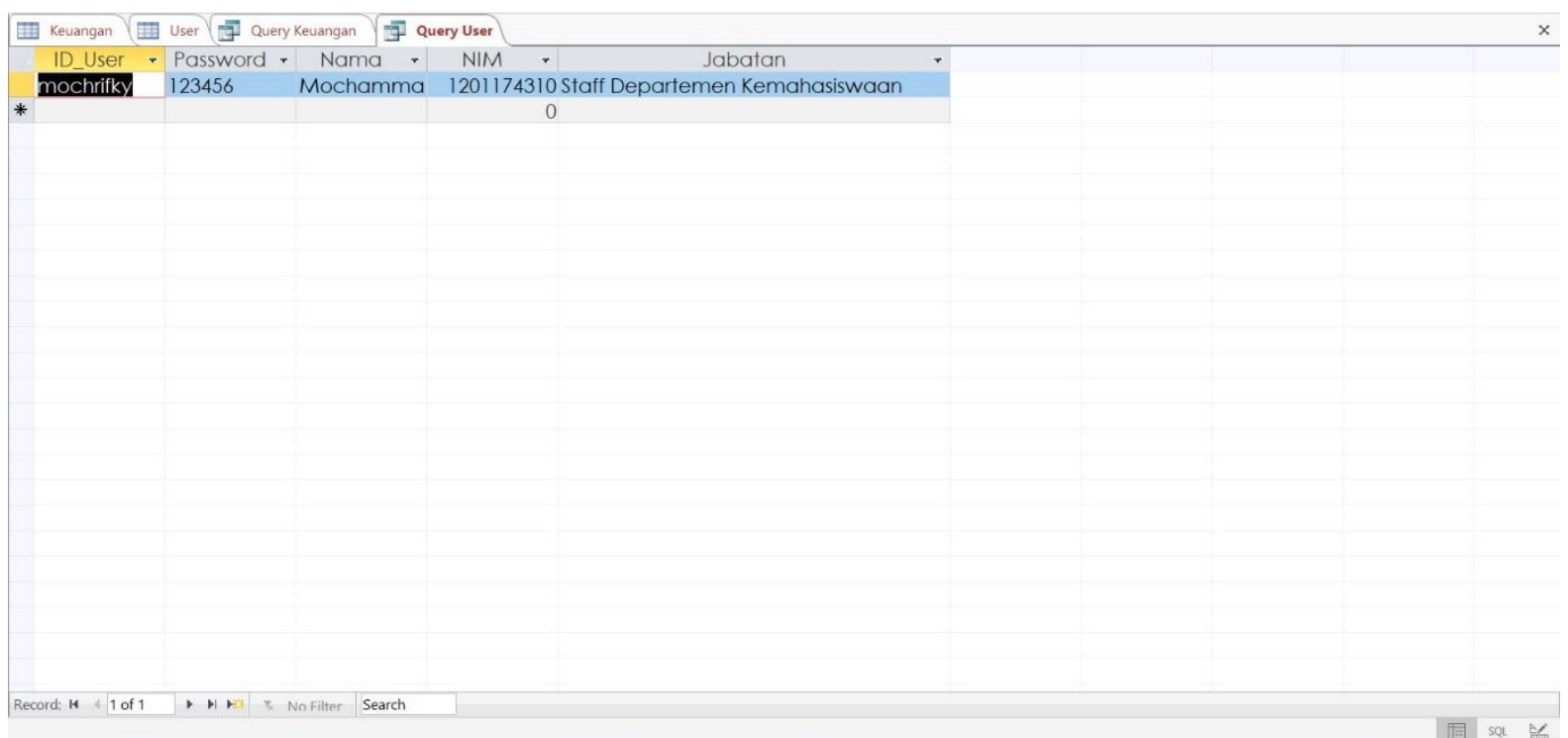

Figure 11. Gambar Interface Design Query User 


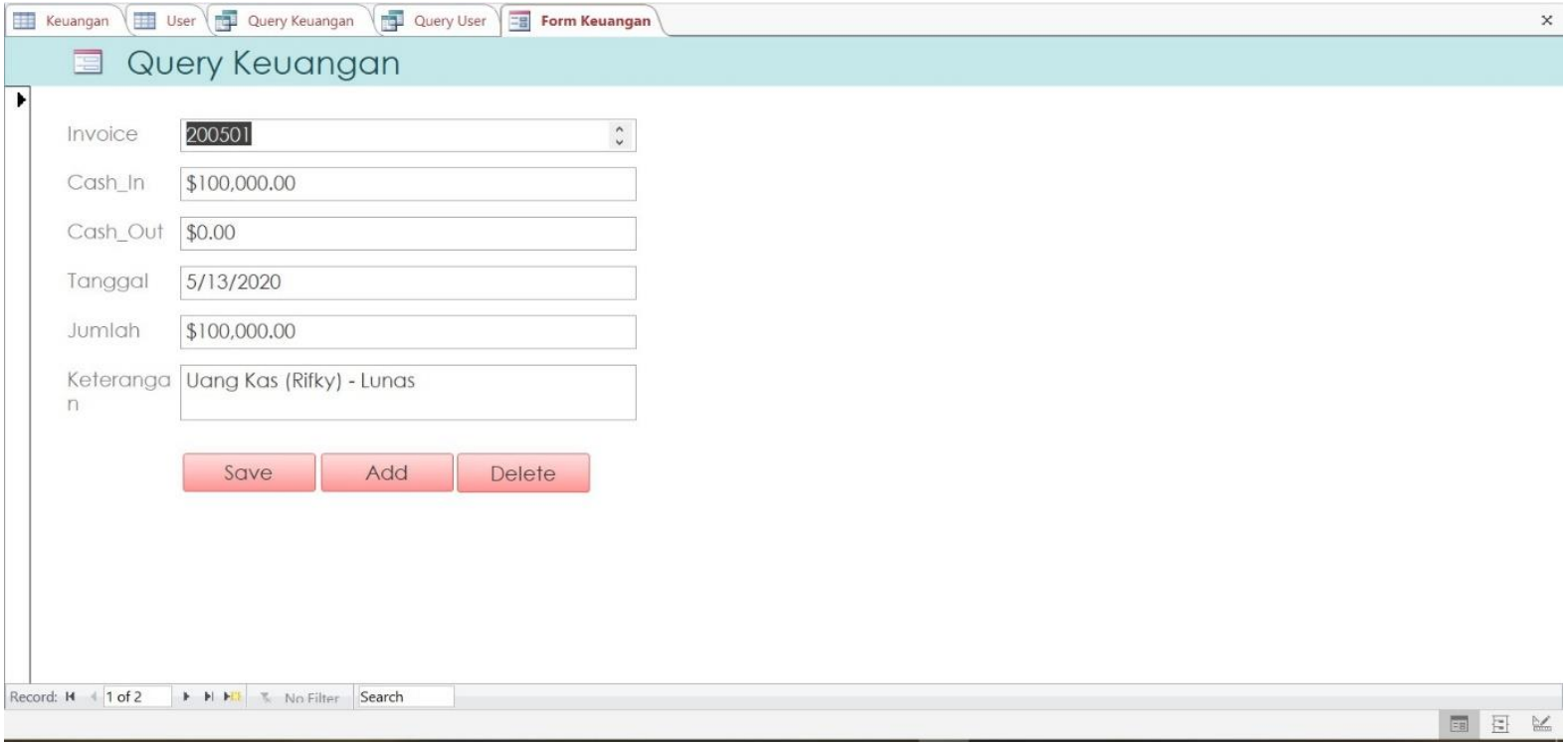

Figure 12. Gambar Interface Design Form Keuangan

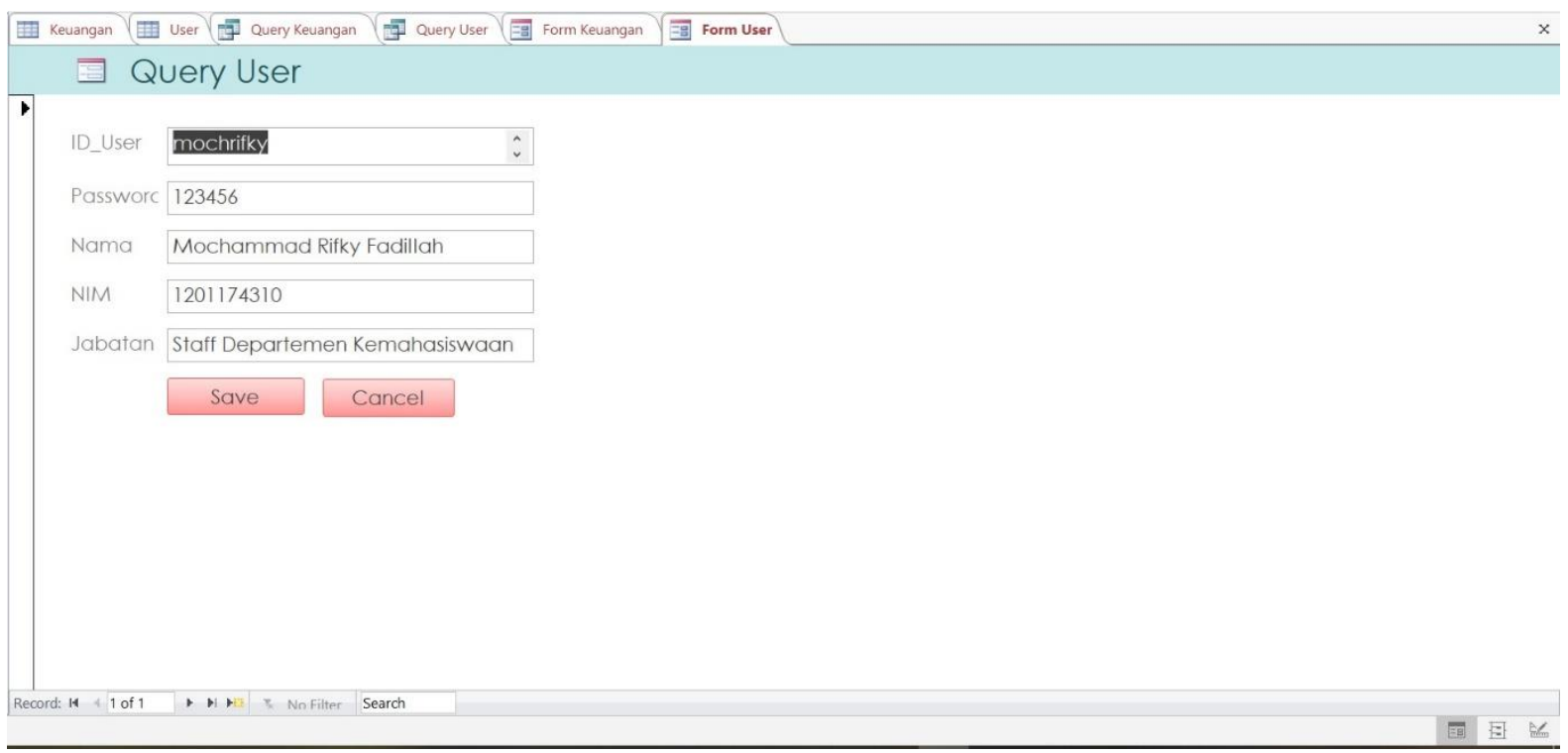

Figure 13. Gambar Interface Design Form User 


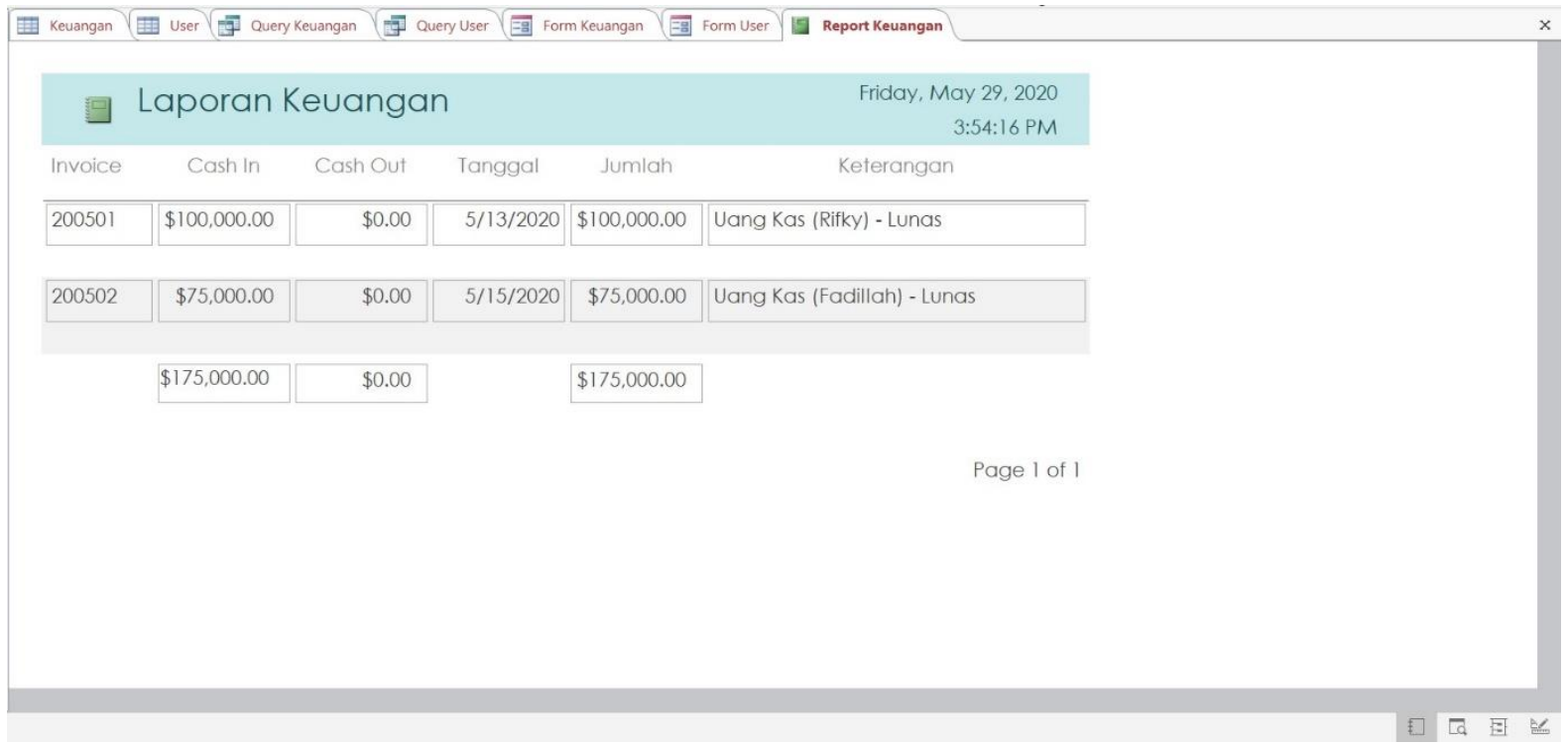

Figure 14. Gambar Interface Design Report Keuangan

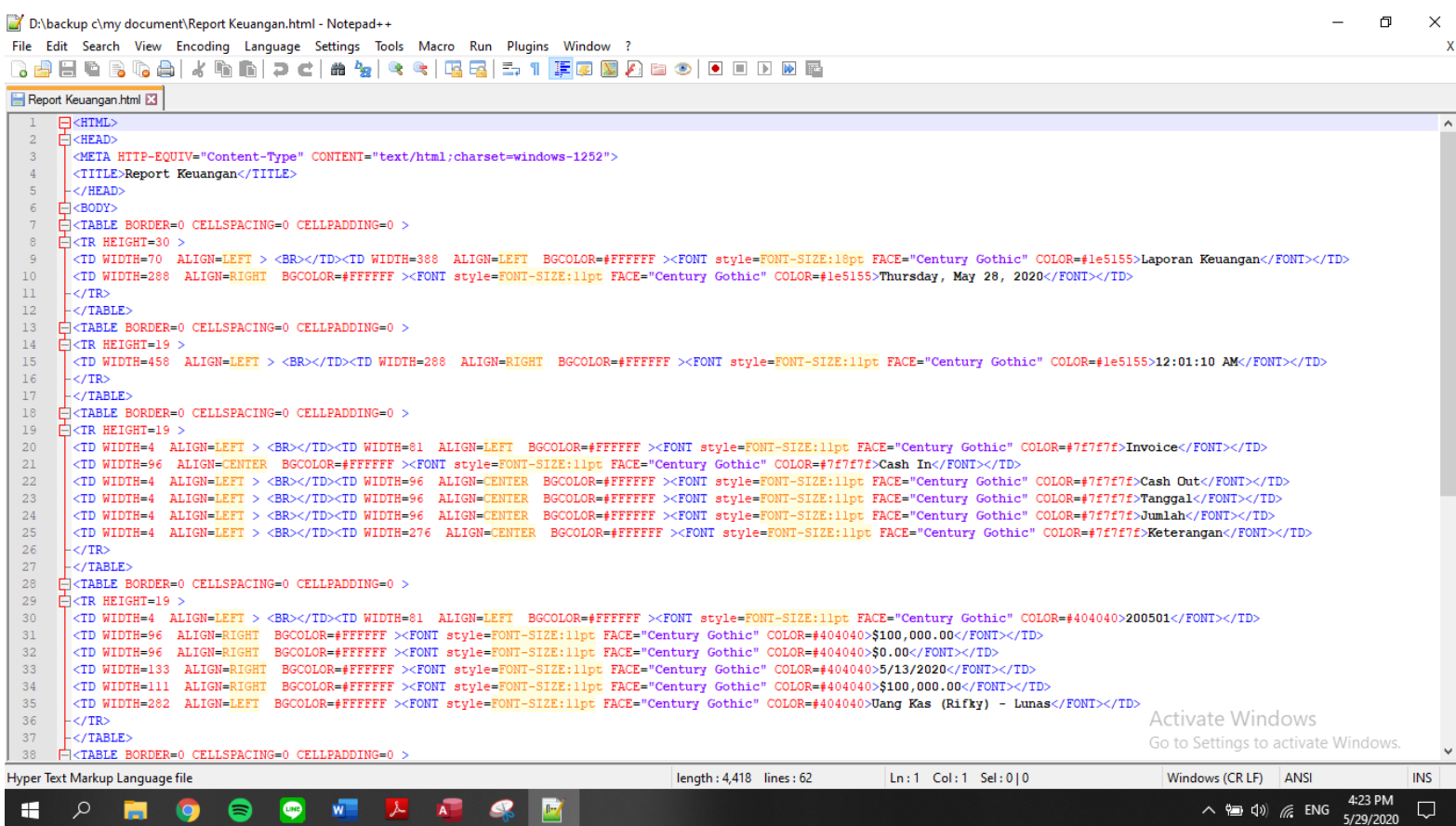

Figure 15. Gambar Source Code Sistem Informasi 


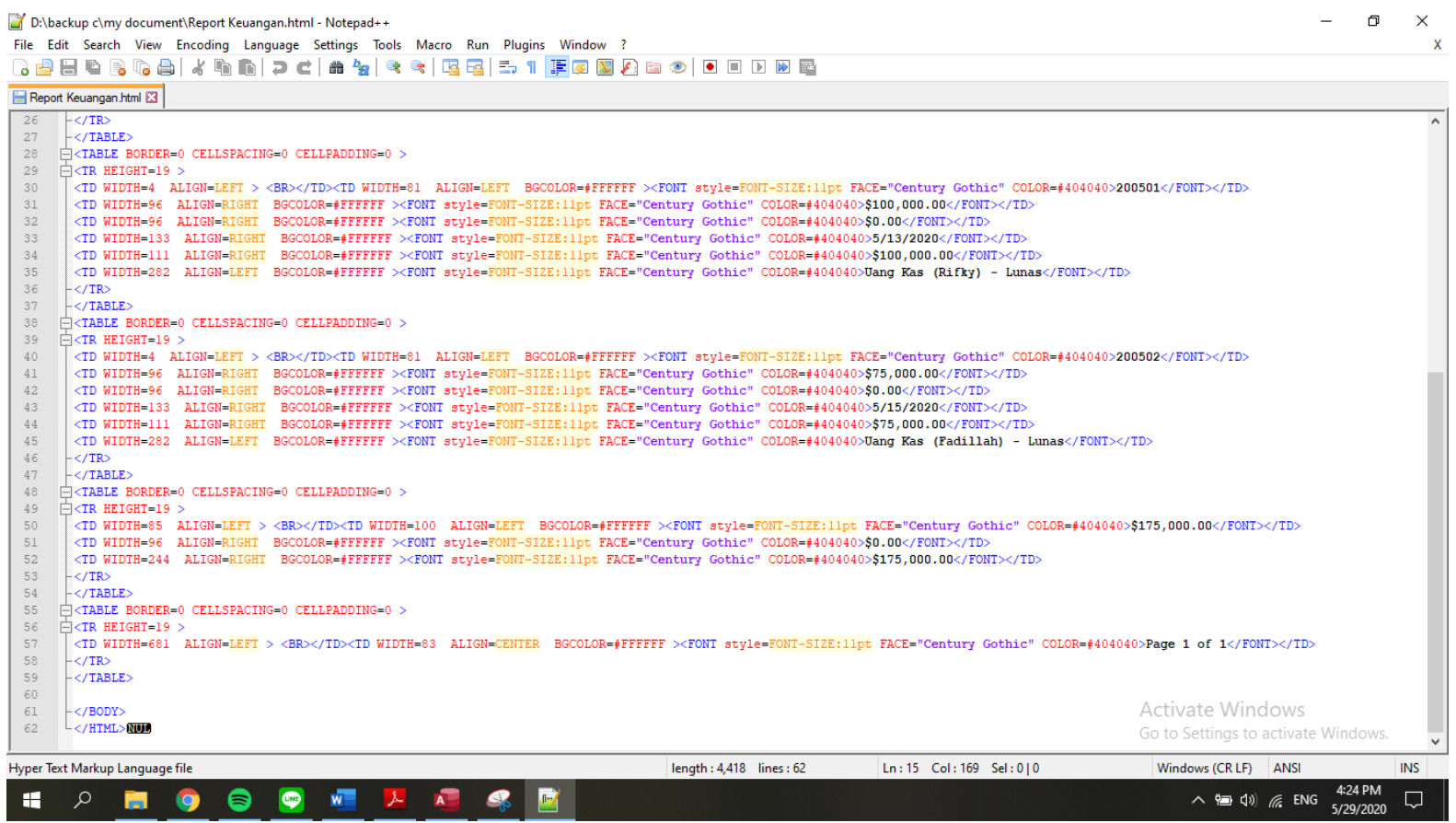

Figure 16. Gambar Source Code Sistem Informasi (Lanjutan)

\subsection{Source Code}

Kode sumber (dapat disebut juga sebagai sumber atau kode) adalah versi perangkat lunak sebagaimana aslinya ditulis (diketik di komputer) oleh manusia dalam teksbiasa (karakter alfanumerik yang dapat dibaca manusia) [5]. Kode sumber pada sistem informasi dapat dilihat pada Figure 15-16.

\section{Penutup}

\subsection{Kesimpulan}

Dalam menjalankan organisasi seperti HMTI, diperlukan sistem informasi seperti yang telah dijelaskan pada paper ini. Sistem informasi keuangan sangat diperlukan untuk kebutuhan transparasi proses keuangan yang dilakukan. Selain itu juga, sistem informasi ini juga dapat mempermudah pencatatan dan juga pelaporan keuangan terhadap anggota organisasi yang lain.

\subsection{Saran}

Sistem informasi ini akan lebih bermanfaat jika ditambahkan fitur-fitur lain yang dapat mempermudah dan mencapai tujuan dari organisasi.

\section{References}

[1] Jogiyanto, H.M, 2005. Analisis dan Desain Sistem Informasi. Penerbit Andi, Yogyakarta.

[2] O'Brien dan Marakas, 2010. Management System Information. McGraw Hill, New York.

[3] Stair, R. M., \& Reynolds, G. W., 2010. Principles of Information Systems: A Managerial Approach. Mass: Course Technology, Cengage Learning, Boston.

[4] Hoffer, J. A., George, J. F., \& Valacich, J. S., 2017. Modern Systems Analysis and Design: $8^{\text {th }}$ Edition. Pearson Prentice Hall, Upper Saddle River, N.J.

[5] The Linux Information Project, 2004. Source Code Definition. LINFO. Available on: http://www.linfo.org/source code.html. Retrieved on May 29, 2020.

Additional

[a] R. Aurachman, "Review Terhadap OSF.IO Sebagai Sarana Publikasi Preprint," OSF Preprints, 17 May 2020. doi:10.31219/osf.io/rvumx , Available: https://osf.io rvumx 
[b] R. Aurachman, "Kerangka Perancangan Sistem Informasi Sebagai Pembelajaran Mahasiswa Teknik Industri," osf.io, doi:10.31219/osf.io/tmpen , 5 2020. Available: https://osf.io/tmpen 